\title{
FEATURE Conservation strategies to adapt to projected climate change impacts in Malawi
}

\author{
Gertrude Kambauwa, James Mlamba, Jorge A. Delgado, and Vernon Kabambe
}

\section{CLIMATE CHANGE AND FOOD SECURITY IN MALAWI}

There is potential for climate change to have negative effects on agricultural production via extreme events (Pruski and Nearing 2002; Zhang et al.2012; Walthall et al.2012), and there is a need to implement conservation practices for climate change adaptation (Delgado et al. 2011, 2013). Recent reports from the Intergovernmental Panel on Climate Change project that rainfall intensities will increase in many parts of the world, increasing the potential for soil erosion (IPCC 2007). However, for other areas, such as the southwestern United States and southern Africa (which includes Malawi), lower precipitation and higher temperatures are projected (IPCC 2007; Walthall et al. 2012). These projected changes in climate (i.e., drier climate, droughts, and extreme events) could contribute to lower yields in this region (Auffhammer 2011; Lobell et al. 2011) and generate conditions that will decrease the potential for future food security in the region. Delgado et al. (2011) reported that due to a combination of challenges related to climate change, population growth, extreme weather events, depletion of water resources in key agricultural regions, and other global challenges, conservation practices will be key for climate change adaptation. For Malawi, achieving food security at the present with the current challenges is difficult, and since these challenges are projected to significantly increase as the climate changes, there is an urgent need to start implementing climate change adaptation practices to increase the potential to achieve food security.

Gertrude Kambauwa is chief land management training officer, Ministry of Agriculture, Irrigation and Water Development, Department of Land Resources Conservation, Lilongwe, Malawi. James Mlamba is an environmental and natural resources management specialist, Concern Worldwide, Nkhotakota, Malawi. Jorge A. Delgado is a soil scientist and acting research leader, USDA Agricultural Research Service, Fort Collins, Colorado, United States. Vernon Kabambe is a professor, Lilongwe University of Agriculture and Natural Resources, Lilongwe, Malawi.
The current average maize (Zea mays L.) production per hectare for Malawi is very low, with a 2014 annual average yield of $2.3 \mathrm{t} \mathrm{ha}^{-1}\left(1.0 \mathrm{tn} \mathrm{ac}^{-1}\right.$ ) (FAO 2014). The Food and Agriculture Organization of the United Nations (FAO) reported that these low yields were $6 \%$ higher than the yields that were obtained during the 2012 to 2013 growing season, due to favorable weather during the 2013 to 2014 growing season and the government fertilizer input subsidy program. Maize is the principal crop for Malawi and a major staple in the country (FAO 2014). Malawi is reported to have the highest per capita maize consumption in the world at 148 $\mathrm{kg}(326 \mathrm{lb})$ per person (Smale and Jayne 2003). Increasing the current maize yields and maintaining these increased yields in the future is important, especially since the population of Malawi is expected to double by 2035 .

Arndt et al. (2014) conducted an analysis of future climate change impacts on the economic growth of Malawi. Their analysis included a climate, biophysical, and economic model to assess the potential effects of climate change on economic growth. The analysis by Arndt et al. (2014) strongly suggests that during the next two decades the economic growth for Malawi will not be affected, but that by 2030 , and certainly after 2040, climate change will significantly impact Malawi's economic growth. They projected that due to climate change average maize yields in Malawi will decline by $2 \%$ during the next three to four decades. Other scientists have reported that climate change's effects in Africa could reduce maize yields by a much larger percentage. The impacts of drought and changes in temperature could lower the maize yields an average of at least 20\% across Africa (Auffhammer 2011; Lobell et al. 2011). Arndt et al. (2014) reported that since policies take some time to develop and implement, it is important to start applying policies now that will contribute to climate change adaptation; the next two decades for Malawi will be critical, and the country will have to start looking for policies that could help it adapt to future changes.

Poppy et al. (2014) conducted similar studies about the potential effects of climate change on food security in Malawi. Although Poppy et al. (2014) found similar trends as Arndt et al. (2014), Poppy et al. (2014) found with their simulations and analysis that the effects of climate change could occur sooner and the negative impacts could be much greater. Poppy et al. (2014) reported that this "perfect storm" will contribute to the generation of a situation where close to $100 \%$ of the population of Malawi is undernourished by 2030. This is of serious concern, especially since the population will have doubled in the next two decades. Malawi will need maize varieties that will be able to adapt to higher temperatures and droughts since yields will be reduced due to extreme events.

Poppy et al. (2014) reported on the limitations of their study and concluded that because of those limitations their analysis should be interpreted as an indicator of potential exposure to undernourishment. These studies are also an indication of the potential negative effects of climate change and population growth on the population in Malawi in the next two decades, such as a projected steep increase in the undernourished population from 2010 to 2030 . Poppy et al. (2014) found from their data analysis that independent of the limitations of their study, this steep increase in undernourishment needs to be interpreted as a critical point of action for policy implementation to increase maize yields with improved technologies and ecosystem services. They concluded that "business as usual in science, agriculture, and ecosystem management" will not function as a policy implementation to adapt to climate change and that this approach is not viable to meet short- and long-term challenges. Malawi, which is located in sub-Saharan Africa, is one of the world's poorest countries, with $39 \%$ of the population living on less than US $\$ 1 \mathrm{~d}^{-1}$ (Poppy et al. 2014). Eighty-five percent of the population lives in rural areas, with $80 \%$ of this rural pop- 
ulation growing rain-fed maize as their primary crop, and for them there is a need for a "policy-relevant climate vulnerability model” (Malcomb et al. 2014).

Different scientists have reported that the effects of climate change have started to occur or are being felt in certain villages of Malawi. Nkomwa et al. (2014) reported that there are examples of local people in small villages worried about climate change and who are noticing changes in climate. Nkomwa et al. (2014) gave as an example Chagaka Village, which is using more drought-tolerant crops such as pearl millet (Pennisetum glaucum [L.]R.Br.) and sorghum (S. bicolor [L.] Moench) and early-yielding varieties as their adaptation strategies for the climate change observed during the last decade. Other strategies to adapt to climate change that are being adopted are management practices to increase water storage in the soil profile (Nkomwa et al. 2014).

\section{INCREASING MAIZE YIELDS IN MALAWI} WITH NITROGEN FERTILIZER

Turner and Rao (2013) conducted studies evaluating simulated responses of sorghum to increases in temperature in eastern and southern Africa (Kenya, Malawi, and Zimbabwe). They reported that smallholder farmers who do not apply nitrogen (N) fertilizer, or who apply $\mathrm{N}$ fertilizer at low levels, have such low yields that they will not immediately see a reduction in the yields from the increase in temperature. Turner and Rao (2013) found that systems that apply $\mathrm{N}$ fertilizer and have higher yields will be more susceptible to being impacted and have larger reductions in yields from climate change. This could be correlated with the use of water since greater yields and greater aboveground biomass production will require greater water use and will then be more susceptible to periods of drought. However, they reported that these higher yields from higher $\mathrm{N}$ fertilizer inputs, even if impacted by periods of drought, should still be higher than yields of maize with no fertilizer, or maize fertilized with low inputs of N. As far as malnutrition, they acknowledge that with the current low yields in Malawi, if farmers are to overcome malnutrition they will have to increase their yields. Turner and Rao (2013) reported that $\mathrm{N}$ fertilizer could contribute to increased yields even in the hottest and driest areas but with an increased risk of crop failure. Their study was conducted with sorghum, which is a more drought-tolerant crop than maize.

Although $70 \%$ percent of the crop area in Malawi is covered by maize, the most important crop in the country, less than half of the maize area (35\%) uses fertilizer, with an average $\mathrm{N}$ fertilizer input rate of $39 \mathrm{~kg}$ $\mathrm{N} \mathrm{ha}^{-1}$ (34.8 $\mathrm{lb} \mathrm{N} \mathrm{ac}^{-1}$ ) (Sauer and Tchale 2009). Sauer and Tchale (2009) reported that average soil organic matter in these soils is low, at $1 \%$. They conducted an $\mathrm{N}$ management survey and found a correlation between $\mathrm{N}$ inputs to maize systems and yields, with a census average of $0.2,1.5$, 1.9, and $2.6 \mathrm{t} \mathrm{ha}^{-1}(0.1,0.7,0.8$, and $1.2 \mathrm{tn}$ $\mathrm{ac}^{-1}$ ) for low, low to moderate, moderate, and high $\mathrm{N}$ inputs, respectively. The Sauer and Tchale (2009) census considered N input of 0 to $34 \mathrm{~kg} \mathrm{~N} \mathrm{ha}^{-1}$ (0 to $30.4 \mathrm{lb} \mathrm{N}$ $\mathrm{ac}^{-1}$ ) to be low, 35 to $90 \mathrm{~kg} \mathrm{~N} \mathrm{ha}^{-1}$ (31.3 to $80.4 \mathrm{lb} \mathrm{N} \mathrm{ac}^{-1}$ ) to be moderate, and $>90 \mathrm{~kg}$ $\mathrm{N} \mathrm{ha}^{-1}\left(>80.4 \mathrm{lb} \mathrm{N} \mathrm{ac}^{-1}\right)$ to be high.

Ngwira et al. (2013a) conducted a fouryear $\mathrm{N}$ input study with maize across nine different sites in Malawi. They found that the control (zero $\mathrm{N}$ fertilizer) had average yields of $1.6 \mathrm{t} \mathrm{ha}^{-1}\left(0.7 \mathrm{tn} \mathrm{ac}^{-1}\right)$. The treatment of $69 \mathrm{~kg} \mathrm{~N} \mathrm{ha}^{-1}\left(61.6 \mathrm{lb} \mathrm{N} \mathrm{ac}^{-1}\right.$ ) significantly increased the average yields to $5.5 \mathrm{t} \mathrm{ha}^{-1}\left(2.5 \mathrm{tn} \mathrm{ac}^{-1}\right)$, and the combination of manure and fertilizer had average yields of $4.8 \mathrm{t} \mathrm{ha}^{-1}\left(2.1 \mathrm{tn} \mathrm{ac}^{-1}\right)$. Ngwira et al. (2013a) concluded that the application of just fertilizer for maize production with hybrid maize can be a productive, viable management practice if the farmer has proper storage facilities. The average yields for treatments with $\mathrm{N}$ fertilizer ranged from $5 \mathrm{t} \mathrm{ha}^{-1}$ to $7.5 \mathrm{tha}^{-1}$ (2.2 and $3.3 \mathrm{tn} \mathrm{ac}^{-1}$ ) for the more productive sites (six of the nine sites), which was significantly higher than the average yields for the control (zero fertilizer), which ranged from about 1 to $2.2 \mathrm{t} \mathrm{ha}^{-1}$ (0.4 and $1.0 \mathrm{tn}$ $\mathrm{ac}^{-1}$ ). For the less productive sites (three of the nine sites), the yields for areas receiving $\mathrm{N}$ fertilizer inputs ranged from 1.8 to $3.8 \mathrm{t} \mathrm{ha}^{-1}$ (0.8 and $\left.1.7 \mathrm{tn} \mathrm{ac}^{-1}\right)$, which was still higher than the yields obtained with the control (zero $\mathrm{N}$ fertilizer), which ranged from 0.4 to $2.1 \mathrm{t} \mathrm{ha}^{-1}(0.2$ and 0.9 tn $\mathrm{ac}^{-1}$ ). Ngwira et al. (2013a) reported that the yield responses to $\mathrm{N}$ fertilizer were higher $(300 \%)$ in the areas that are more productive than the yield responses to $\mathrm{N}$ fertilizer in the less productive zones (200\% to $300 \%)$.

Kamanga et al. (2014) conducted studies with small amounts of fertilizer at the rates of 15 and $30 \mathrm{~kg} \mathrm{~N} \mathrm{ha}{ }^{-1}$ (13.4 to 26.8 lb $\mathrm{N} \mathrm{ac}^{-1}$ ), which were applied to fields by smallholder maize farmers in Malawi. Even at these low inputs of fertilizer, Kamanga et al. (2014) found positive responses to fertilizer applications. The applied fertilizer increased the yields of maize from 0.65 to $1.5 \mathrm{t} \mathrm{ha}^{-1}$ (0.3 and $0.7 \mathrm{tn} \mathrm{ac}^{-1}$ ) when the field was weeded twice and from 0.4 to $0.9 \mathrm{t} \mathrm{ha}^{-1}$ (0.2 and $\left.0.4 \mathrm{tn} \mathrm{ac}^{-1}\right)$ when the field was weeded only once. Nitrogen fertilizer can be used to increase yields in Malawi (Benson 1999; Kamanga et al. 2014; Ngwira et al. 2013a; Sauer and Tchale 2009; Turner and Rao 2013).

Snapp (2008) conducted studies (1,130 total samples) about the soil chemical and physical properties of five of the eight agricultural development divisions of Malawi. Snapp (2008) reported that in general, the dominant soil texture across Malawi is loamy sand, and as far as the $\mathrm{pH}$, the soils were in general moderately acidic. The soil organic carbon (C) content was low and averaged $1.4 \%$, with a low $\mathrm{N}$ mineralization potential. Snapp (2008) reported that the soil potassium $(\mathrm{K})$ and calcium $(\mathrm{Ca})$ levels across the country are sufficient for crop production. As far as soil phosphorus (P) levels, Snapp (2008) reported that some areas have low $\mathrm{P}$ levels that could contribute to deficient levels of $\mathrm{P}$ for crops, while other areas have sufficient levels of $\mathrm{P}$ for adequate crop production. As far as micronutrients, soils in the Ezda region were reported to have low zinc (Zn) content (Snapp 2008).

\section{INCREASING MAIZE YIELDS IN MALAWI WITH CONSERVATION AGRICULTURE}

Thierfelder et al. (2012) conducted longterm studies (8 years) in Zimbabwe and found that conservation agriculture had advantages over conventional agriculture. Direct seeding with conservation agriculture increased yields compared to the conventional tillage systems. They found that rotations with cover crops and leguminous 
crops using direct seeding with conservation agriculture increased yields even more compared to the conventional tillage systems. In Malawi, Ngwira et al. (2013b) reported that conservation agriculture increased average yields in 12 different sites in Malawi from 2005 to 2011 by $22 \%$ to $26 \%$. However, they found that the increases in yields were dependent on the agroecological region. In the low-rainfall, low-altitude areas of Balaka and Machinga, conservation agriculture increased yields by $31.3 \%$ and $67.7 \%$, respectively. However, in the higher altitude, wetter areas of Chipeni and Enyenzi, conservation agriculture reduced the average yields (although not significantly) by $1.6 \%$ and $14.9 \%$, respectively. These studies from Ngwira et al. (2013b) suggest a need for studying the spatial responses to conservation agriculture and a need to consider not only yield increase but net responses when comparing conservation agriculture and conventional systems. There is potential to use conservation agriculture to adapt to climate change (FAO 2009; Thiombiano and Meshack 2009; Ngwira et al. 2013b; Delgado et al. 2011).

\section{NECESSITY OF CONSIDERING THE HUMAN DIMENSION TO INCREASE MAIZE YIELDS IN MALAWI}

Ricker-Gilbert et al. (2011) studied the effects of fertilizer on the production of maize in Malawi and found a residual effect since users of fertilizer in fields that were not fertilized in previous years increased their yields by $1.8 \mathrm{~kg} \mathrm{~kg}^{-1}\left(4.0 \mathrm{lb} \mathrm{lb}^{-1}\right)$ of fertilizer applied, which was much lower than the increase in yields observed for users of fertilizer in fields that were fertilized the previous three years, who increased their yield by $3.2 \mathrm{~kg}$ maize $\mathrm{kg}^{-1}$ (7.1 lb maize $\mathrm{lb}^{-1}$ ) of fertilizer applied. These data suggest that there is an effect of residual $\mathrm{N}$ inputs due to residual inorganic $\mathrm{N}$ or due to $\mathrm{N}$ cycling in the system that is contributing to higher yields. Higher yields could also contribute to higher belowground soil organic matter that could contribute to other biogeochemical benefits.

Lunduka et al. (2013) conducted a cost-benefits analysis of subsidized fertilizer from 2005/2006 to 2008/2009. Lunduka et al. (2013) concluded that the incentive programs of maize fertilizer sub- sidies were not very effective at increasing yields and food security. They proposed several recommendations for improving the programs. For example, one of their recommendations was that the programs be improved in such a way to increase timely application of fertilizer, since the distribution of the product may not occur when the fertilizer is needed. Lunduka et al. (2013) shows that increasing food security is not just a scientific question as far as determining the soil and physical factors, but that there is also a human dimension and social aspects that are very important for food security as well as the effectiveness of subsidized programs. These are examples of how the human dimension of conservation is an important aspect to consider in climate change adaptation efforts and examples of how management decisions (Lal et al. 2011) and conservation practices (Delgado et al. 2011) are important factors in adapting to climate change.

Sauer et al. (2007) reported that integrated soil fertility management that includes use of legumes and inorganic fertilizer contributes to improved yields; this is important because all farmers may not be able to use inorganic $\mathrm{N}$ fertilizer alone at the needed rates. Sauer et al. (2007) reported that other sources of $\mathrm{N}$, such as leguminous crops, with improved management could contribute to increased maize yields. This is in agreement with the findings from the Phiri et al. (1999) study of the effects of $\mathrm{N}$ fertilizer added at a rate of $120 \mathrm{~kg} \mathrm{~N} \mathrm{ha}{ }^{-1}$ (107.1 lb N ac $\mathrm{lb}^{-1}$ ) compared to the control (zero $\mathrm{N}$ fertilizer) and to an organic treatment only applying the leguminous crop, sesbania (Sabanian sesban). Phiri et al. (1999) found that the maize yields were still low at 1.7, 2.1, and $0.5 \mathrm{Mg} \mathrm{ha}^{-1}\left(0.8,0.9\right.$, and $\left.0.2 \mathrm{tn} \mathrm{ac}^{-1}\right)$ for the organic treatment (sesbania), $\mathrm{N}$ fertilizer treatment, and control (zero fertilizer) plots, respectively. They discovered a high accumulation of residual soil nitrate $\left(\mathrm{NO}_{3}\right)$ in the soil profile of about 53,33 , and 24 $\mathrm{kg} \mathrm{N} \mathrm{ha}^{-1}\left(47.3,29.5\right.$, and $\left.21.4 \mathrm{lb} \mathrm{N} \mathrm{ac}^{-1}\right)$ for the inorganic $\mathrm{N}$ fertilizer treatment, sesbania (leguminous) treatment, and control (zero fertilizer) plots, respectively. After 85 days with the sesbania treatment, the soil inorganic $\mathrm{N}$ content was higher than that of the control (no fertilizer) plots.
Because of the slow mineralization of the leguminous crop they recommended that the input also be combined with the use of inorganic $\mathrm{N}$ fertilizer. All of these studies show that there is a need to transfer more than the fertilizer or seeds to a farmer, and that a technology package to improve management of water, planting, cultivation practices, and $\mathrm{N}$ fertilizer use to achieve potentially higher yields is needed.

Training is also needed on how to make the best decisions for $\mathrm{N}$ management (figures 1 and 2). New technologies such as the Nitrogen Index Tool, which can be applied in low-intensive systems or even be run in smartphones, have shown potential to help people make decisions about $\mathrm{N}$ management practices (Monar et al. 2013; Delgado et al. 2013). The USDA Foreign Agricultural Service, University of Missouri, and USDA Agricultural Research Service have been cooperating with Malawi's Ministry of Agriculture, Irrigation, and Water Development in technology transfer for implementation of conservation agriculture and improved management practices. As part of this cooperation, the new Malawi Nitrogen Index has been developed and transferred to the Ministry of Agriculture and Food Security in Malawi.The tool can be used to integrate information about management practices in Malawi, to provide a quick assessment of the $\mathrm{N}$ balance, and to generate recommendations for $\mathrm{N}$ fertilizer application in Malawi. The tool can also assess potential residual soil $\mathrm{NO}_{3}$ and pathways for $\mathrm{N}$ losses, including emissions of nitrous oxide $\left(\mathrm{N}_{2} \mathrm{O}\right)$.

\section{SUMMARY}

The peer-reviewed scientific literature strongly suggests that Malawi is at a crossroads as far as implementing policies that are needed for climate change adaptation. Papers have reported that the population growth and effects from climate change that have been projected to occur could significantly impact food security, increasing the percentage of the malnourished population in Malawi to close to $100 \%$ in the next two decades. The literature suggests that if policies that are oriented towards climate change adaptation are not implemented, the potential to maintain and/or achieve food security will be 


\section{Figure 1}

Malawi Nitrogen Index workshop participants conducting evaluations of nitrogen management practices on their laptops after installation of the software.

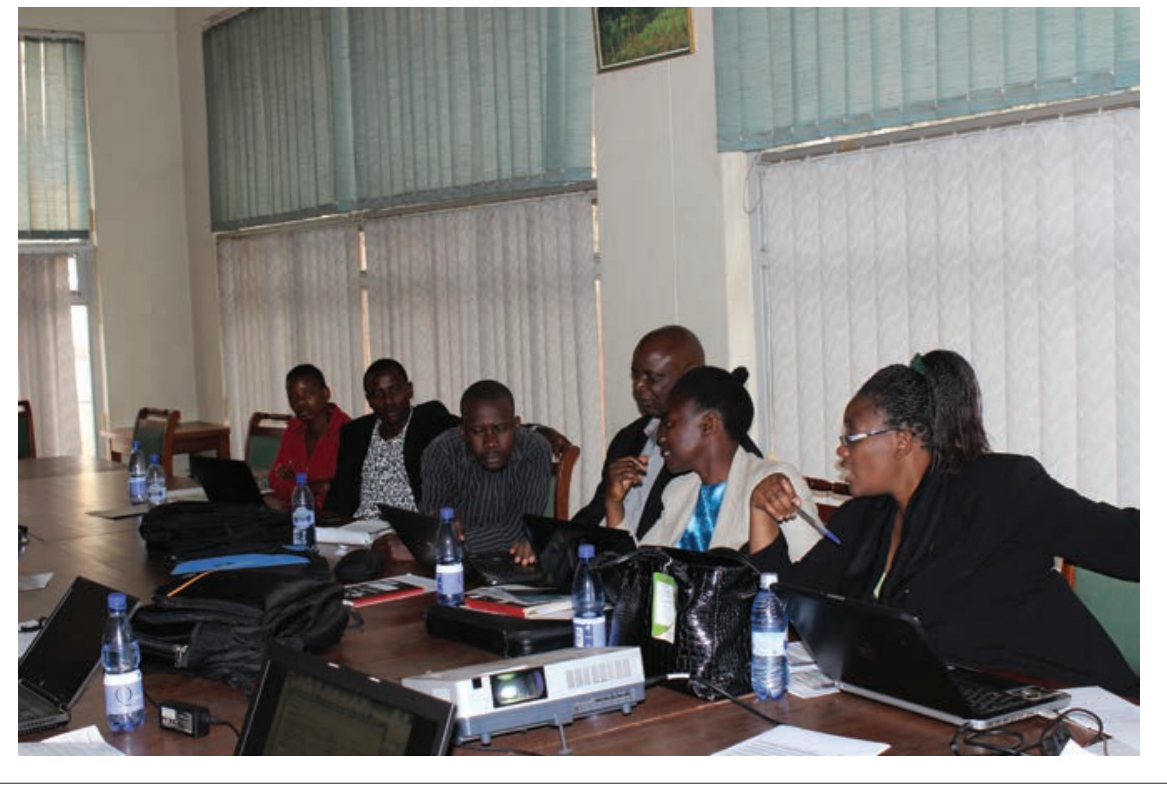

\section{Figure 2}

Output screen of the Malawi Nitrogen Index Tier Zero prototype.

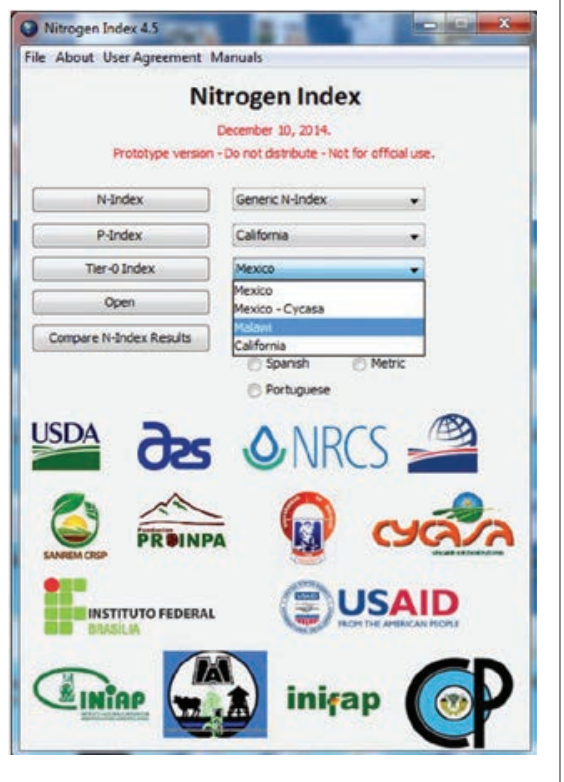

significantly diminished. This is in agreement with the Delgado et al. (2011) paper, which reviewed the scientific literature on climate change and conservation practices, and in agreement with the position statement from the Soil and Water Conservation Society about the impor- tance of conservation practices for climate change adaptation.

The literature supports the use of conservation agriculture to adapt to climate change and increase yields. Yields can be increased with $\mathrm{N}$ fertilizer application, improved seed, and crop varieties that can better adapt to climate change. There is potential to use these technologies to double and triple yields across different regions of Malawi, especially in the most productive regions of Malawi. Other approaches that can contribute to climate change adaptation are the use of leguminous crops and/or manures that can contribute to improved soil quality and increase the $\mathrm{N}$ inputs to maize systems. Integrated systems that use $\mathrm{N}$ fertilizer, leguminous crops, manure inputs, and improved management practices (especially those that can increase water use efficiency) can contribute to climate change adaptation.

There is a need to improve policies and programs to make the current government $\mathrm{N}$ fertilizer input subsidy programs in Malawi more effective. The human factor, where managers decide how to implement best management practices, is also important. Extension agents trained in these topics, as well as new tools, can help users make decisions about how to apply best $\mathrm{N}$ management practices to increase maize yields.

For Malawi and other regions in Africa that could be impacted by lower precipitation and higher temperatures, the challenge is in front of us. However, "business as usual in science, agriculture, and ecosystem management" will not work as an approach to adapt to climate change (Poppy et al. 2014), and there is a need to implement policies for adaptation to climate change (Poppy et al. 2014; Delgado et al. 2011; figures 3 and 4).

\section{REFERENCES}

Arndt, C., A. Schlosser, K. Strzepek, and J. Thurlow. 2014. Climate change and economic growth prospects for Malawi:An uncertainty approach. Journal of African Economies 23(AERC Supplement 2):ii83-ii107, doi:10.1093/jae/eju013.

Auffhammer, M. 2011. Agriculture: Weather dilemma for African maize. Nature Climate Change 1:27-28. Benson, T. 1999. Validating and strengthening the area-specific fertilizer recommendations for hybrid maize grown by Malawian smallholders. A research report of the results of the nationwide 1997/98 Maize Fertilizer Recommendations Demonstration. Action Group 1 Maize Productivity Taskforce.

Delgado, J.A., P.M. Groffman, M.A. Nearing, T. Goddard, D. Reicosky, R. Lal, N.R. Kitchen, C.W. Rice, D. Towery, and P. Salon. 2011. Conservation practices to mitigate and adapt to climate change. Journal of Soil and Water Conservation 66(4):118A-129A, doi:10.2489/jswc.66.4.118A

Delgado, J.A., K.D. Kowalski, and C. Tebbe. 2013. The first Nitrogen Index app for mobile devices: Using portable technology for smart agricultural management. Computers and Electronics in Agriculture 91:121-123.

FAO (Food and Agriculture Organization of the United Nations). 2009.Agriculture and Consumer Protection Department. Conservation Agriculture. Food and Agriculture Organization of the United Nations. http://www.fao.org/ag/ca/

FAO (Food and Agriculture Organization of the United Nations). 2014. GIEWS Country Brief Malawi. Improved national maize supplies following bumper 2014 harvest. Food and Agriculture Organization of the United Nations. http://www.fao.org/giews/countrybrief/country/MWI/pdf/MWI.pdf.

IPCC (Intergovernmental Panel on Climate Change). 2007. Summary for Policymakers. In Climate Change 2007: The Physical Science 


\section{Figure 3}

James Mlamba (first from the left) and Ida Delgado (second from the right) visiting with a farmer's family in Malawi about their maize production. The harvested maize yields are stored in the grain farmer's storage facilities for local consumption of maize.

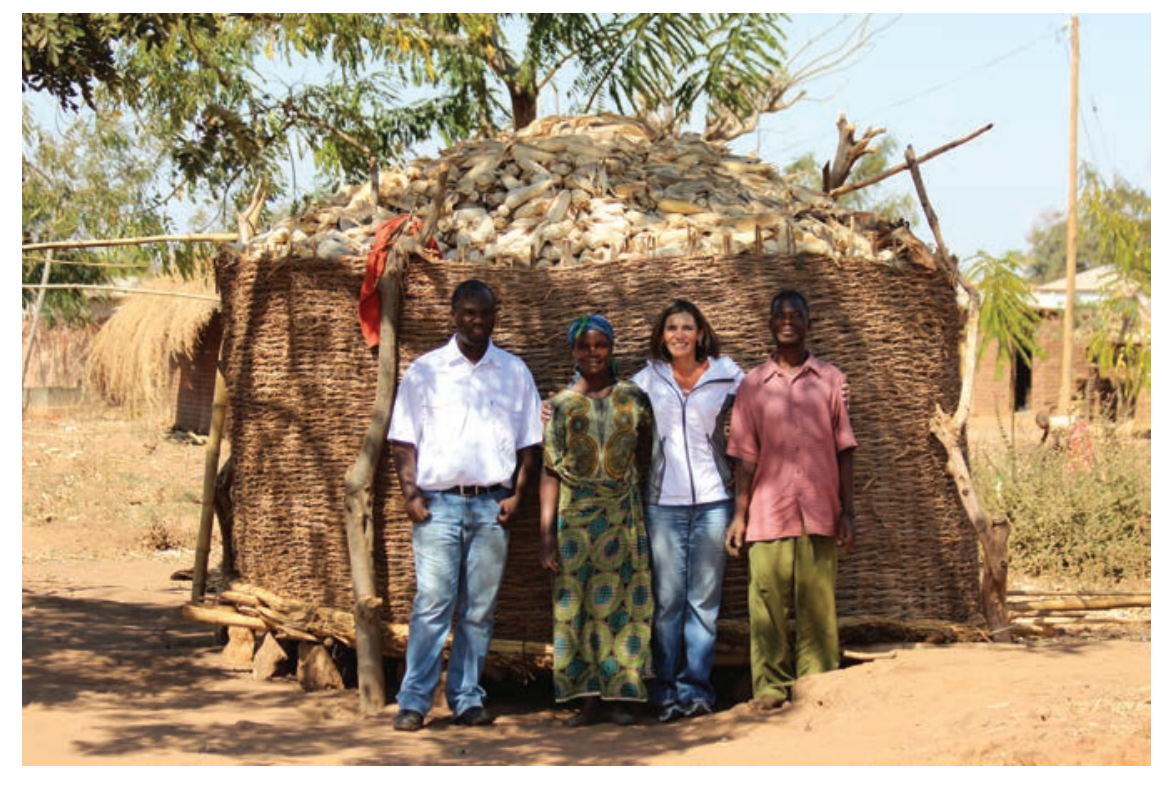

\section{Figure 4}

Field in Malawi where maize is planted in basins complemented with a swale.

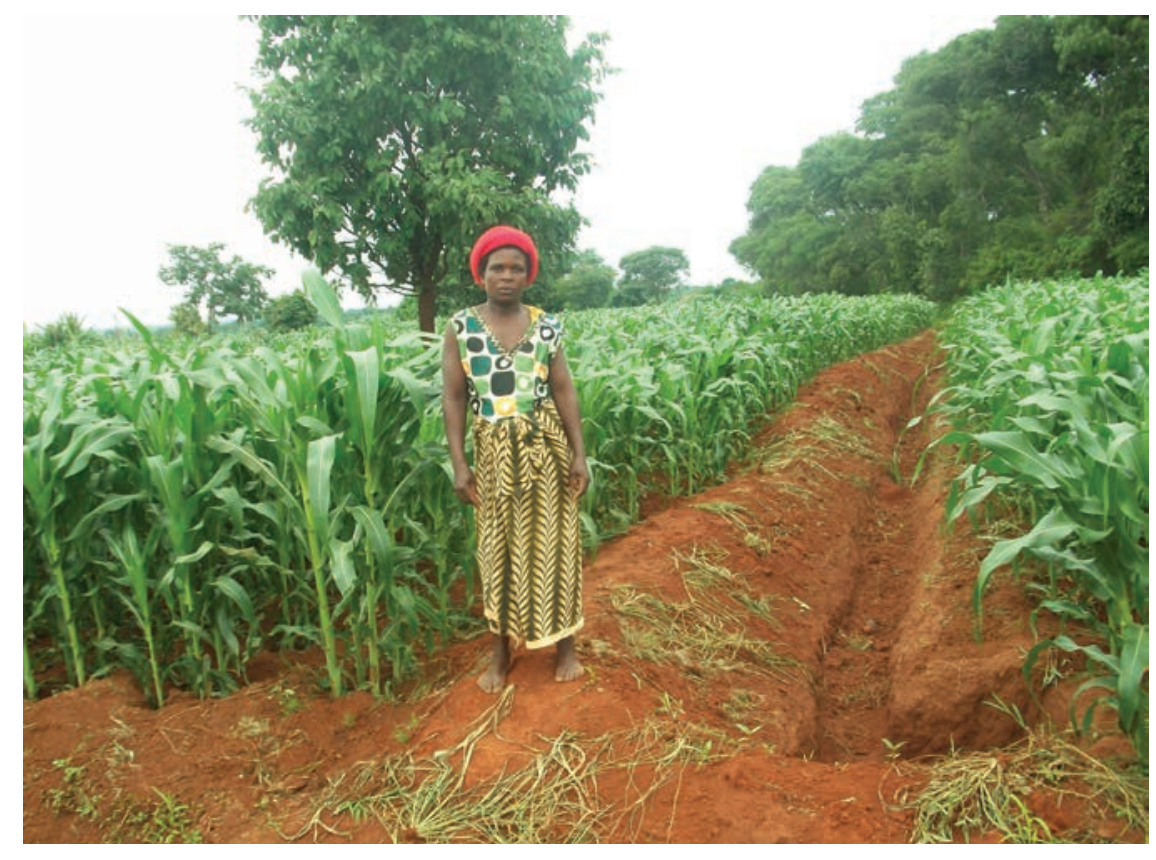

Basis. Contribution of Working Group I to the Fourth Assessment Report of the Intergovernmental Panel on Climate Change, eds. S. Solomon, D. Qin, M. Manning, Z. Chen, M. Marquis, K.B. Averyt, M. Tignor and H.L. Miller. Cambridge, United Kingdom, and New York, USA: Cambridge University Press. https:// holder maize in central Malawi. Experimental Agriculture 50(2):229-249.

Lal, R., J.A. Delgado, P.M. Groffman, N. Millar, C. Dell, and A. Rotz. 2011. Management to mitigate and adapt to climate change. Journal of Soil and Water Conservation 66(4):276-285, doi:10.2489/jswc.66.4.276.

Lobell, D.B., M. Bänziger, C. Magorokosho, and B. Vivek. 2011. Nonlinear heat effects on African maize as evidenced by historical yield trials. Nature Climate Change 1:42-45. http://www. nature.com/natureclimatechange.

Lunduka, R., J. Ricker-Gilbert, and M. Fisher. 2013. What are the farm-level impacts of Malawi's farm input subsidy program? A critical review. Agricultural Economics 44:563-579.

Malcomb, D.W., E.A. Weaver, and A.R. Krakowka. 2014. Vulnerability modeling for sub-Saharan Africa: An operationalized approach in Malawi. Applied Geography 48:17-30.

Monar, C., A.K. Saavedra, L. Escudero, J.A. Delgado, J. Alwang, V. Barrera, and R. Botello. 2013. Positive impacts in soil and water conservation in an Andean region of South America: Case scenarios from a US Agency for International Development multidisciplinary cooperative project. Journal of Soil and Water Conservation 68(1):25-30, doi:10.2489/jswc.68.1.25A.

Nkomwa, E.C., M.K. Joshua, C. Ngongondo, M. Monjerezi, and F. Chipungu. 2014. Assessing indigenous knowledge systems and climate change adaptation strategies in agriculture: A case study of Chagaka Village, Chikhwawa, Southern Malawi. Physics and Chemistry of the Earth 67:164-172.

Ngwira, A.R., M. Nyirenda, and D. Taylor. 2013a. Toward sustainable agriculture: An evaluation of compost and inorganic fertilizer on soil nutrient status and productivity of three maize varieties across multiple sites in Malawi. Agroecology and Sustainable Food Systems 37:859-881.

Ngwira, A.R., C. Thierfelder, N. Eash, and D.M. Lambert. 2013b. Risk and maize-based cropping systems for smallholder Malawi farmers using conservation agriculture technologies. Experimental Agriculture 49:483-503.

Phiri, R.H., S. Snapp, and G.Y. Kanyama-Phiri. 1999. Soil nitrate dynamics in relation to nitrogen source and landscape position in Malawi. Agroforestry Systems 47:253-262.

Poppy, G.M., S. Chiotha, F. Eigenbrod, C.A. Harvey, M. Honzák, M.D. Hudson, A. Jarvis, N.J. Madise, K. Schreckenberg, C.M. Shackleton, F. Villa, and T.P. Dawson. 2014. Food security in a perfect storm: using the ecosystem services framework to increase understanding. 
Philosophical Transactions of the Royal Society B 369:20120288, doi: 0.1098/rstb.2012.0288.

Pruski, F.F., and M.A. Nearing. 2002. Runoff and soil loss responses to changes in precipitation: a computer simulation study. Journal of Soil and Water Conservation 57(1):7-16.

Ricker-Gilbert, J., T.S. Jayne, and E. Chirwa. 2011. Subsidies and crowding out: A double-hurdle model of fertilizer demand in Malawi. American Journal of Agricultural Economics 93(1):26-42.

Sauer, J., and H. Tchale. 2009. The economics of soil fertility management in Malawi. Review of Agricultural Economics 31(3):535-560.

Sauer, J., H. Tchale, and P. Wobst. 2007. Alternative Soil Fertility Management Options in Malawi: An Economic Analysis. Journal of Sustainable Agriculture, 29:29-53

Smale, M., and T. Jayne. 2003. Maize in Eastern and Southern Africa: Seeds of Success in Retrospect. Discussion paper 97. Washington, DC: Environment and Production Technology Division, International Food Policy Research Institute.

Snapp S.S. 1998. Soil nutrient status of smallholder farms in Malawi. Communications in Soil Science and Plant Analysis 29:2571-2588

Thierfelder, C., S. Cheesman, and L. Rusinamhodzi. 2012. A comparative analysis of conservation agriculture systems: Benefits and challenges of rotations and intercropping in Zimbabwe. Field Crops Research 137:237-250.

Thiombiano, L., and M. Meshack. 2009. Scaling-up Conservation Agriculture in Africa: Strategy and Approaches. Addis Ababa, Ethiopia: Food and Agriculture Organization of the United Nations (FAO) Sub Regional Office for Eastern Africa. http://www.fao.org/ag/ca/doc/Kenya\%20 Workshop\%20Proceedings.pdf.

Turner, N.C., and K.P.C. Rao. 2013. Simulation analysis of factors affecting sorghum yield at selected sites in eastern and southern Africa, with emphasis on increasing temperatures. Agricultural Systems 121:53-62.

Walthall, C.L., J. Hatfield, P. Backlund, L. Lengnick, E. Marshall, M. Walsh, S. Adkins, M. Aillery, E.A. Ainsworth, C. Ammann, C.J. Anderson, I. Bartomeus, L.H. Baumgard, F. Booker, B. Bradley, D.M. Blumenthal, J. Bunce, K. Burkey, S.M. Dabney, J.A. Delgado, J. Dukes, A. Funk, K. Garrett, M. Glenn, D.A. Grantz, D. Goodrich, S. Hu, R.C. Izaurralde, R.A.C. Jones, S.-H. Kim, A.D.B. Leaky, K. Lewers, T.L. Mader, A. McClung, J. Morgan, D.J. Muth, M. Nearing, D.M. Oosterhuis, D. Ort, C. Parmesan, W.T. Pettigrew, W. Polley, R. Rader, C. Rice, M. Rivington, E. Rosskopf, W.A. Salas, L.E. Sollenberger, R. Srygley, C. Stöckle, E.S. Takle, D. Timlin, J.W. White, R. Winfree, L. WrightMorton, and L.H. Ziska. 2012. Climate Change and Agriculture in the United States: Effects and Adaptation. USDA Technical Bulletin 1935. Washington, DC: USDA.

Zhang, Y., M. Hernandez, E. Anson, M.A. Nearing, H.Wei, J.J. Stone, and P. Heilman. 2012. Modeling climate change effects on runoff and soil erosion in southeastern Arizona rangelands and implications for mitigation with rangeland conservation practices. Journal of Soil and Water Conservation 67(5):390-405, doi:10.2489/jswc.67.5.390. 